\title{
The role of new product development on export market share
}

\author{
Naser Azad", Seyed Foad Zarifi and Seyed Mohsen Seyed Aliakbar
}

Department of Management, Islamic Azad University, South Tehran Branch, Tehran, Iran, Iran

\section{CHRON I CLE ABSTRACT}

Article history:

Received May 12, 2013

Accepted June 22, 2013

Available online

July 92013

Keywords:

Product development

Market share

Export market

\begin{abstract}
There is an ongoing change on customers' needs on selecting customers' needs, which may influence requirements on designing products and services as well as export sale and company's market shares in domestic and international market. In the present study, through descriptive approach with qualitative method and case study, we investigate important key factors influencing on new product development and products' successive factors at overseas nutritional market. In addition by presenting a new model in accordance with the present condition of the organization we explore the closest product development model and affective factors influencing them. The study investigates 36 factors and extracts six important ones, which influence product development including intelligent information, process research and development, strategy introduced, participation strategy, market survey and differentiation strategy.
\end{abstract}

\section{Introduction}

Product development means manipulating one of the strategies to improve or to reform products and present services to promote their sale balance and market share. Products development itself requires large amount of expenditures in research and development region (David, 1989). Considering consumers' price sensitivity, companies need to be creative and innovative enough for their sale market and encourage others to cooperate in development field. In most of productive activities; product development has a particular place. New products provide new growing opportunities and rivalry advantages for companies. Nowadays company's survival is held hostage to new development tendency and applying appropriate methods for them. Growing importance of new product development in occupation and company's attention toward new products' nature has led to a wide range of research in management knowledge (Pitta et al. 2012). These days, we see a strong and competitive market where firms are constantly under pressure to reduce their prices (Andersen \& Munksgaard, 2009).

* Corresponding author.

E-mail addresses: dr.naserazad@yahoo.com (N. Azad)

(C) 2013 Growing Science Ltd. All rights reserved. doi: $10.5267 /$ j.dsl.2013.07.002 
Many consumers try to find appropriate products, which would meet their requirements and cultural characteristics and companies, on the other side, look for a model to enable the customers to cooperate in development plan too. In fact, they first look at what market is looking for and then they try to extract new ideas. By analyzing the ideas and achieved information the required product plan of both customers and markets is outlined and the process of designing a special model is assigned (Shamsuzzoha et al., 2009). Thus, customers could be involved in developmental affairs and offer different kinds of products to producers as a new product (Munksgaard et al., 2011).

In the modern nutrition market in which customers are extremely attentive on products' quality, improving qualitative guideline is considered to raise company's profit and market share. Besides, since consumers are sensitive to goods' price, assigning a reasonable price is a key element to raise company's product demands. On the other hand, demand's growth in high quality products lead firms to produce products in accordance with consumers' need. This process, of course, concludes all procedures as designing, ordering, producing, selling, even distributing and finally receiving the products by a potential consumer. Wrapping up all these would make progress in securing consumers' welfare (Andersen \& Munksgaard, 2009).

It should be noticed that companies could guarantee the succession of product development plan through affective coordination of all their employees in various regions, because this accelerates the process of development and product's entrance to the market in the shortest possible time. This fast pace itself leads to the victory of the plan. In fact, in addition to personnel coordination, succession is achieved when the company affectively coordinates and merges its entire interior-structure units like marketing, production, R \& D and purchases. Units should meddle in all development process according to their proficiency; then the buyers' required goods are designed and sent to the market. Thus, interior coordination could be considered as an element to achieve the development plan (Lau et al., 2011). Besides, companies could eliminate their interior weaknesses by merging with other companies or consulting with veteran experts. Even in some cases that they're not strong enough to encounter the issue or there is no necessity to be involved, they could refer to outsourcing and gain credibility and prominence which are led to faster innovation and timely superiority in the market (Swan \& and Pitta, 2010).

Of course, two elements could be considered as failure elements of product development plan. First, the length time dedicated to financial and human resources to diagnose customers' need, supply goods and support materials is expensive and they could be considered as a decelerator in continuum of the development process (Lau et al., 2011). The second failure element is the long process of development that could make the customers loses their current anticipation to the good produced by development plan.

In this paper, we present an empirical investigation to find important factors influencing product development on food industry. The organization of this paper first present details of influencing factors in section 2 while section 3 presents details of our results and concluding remarks are given in the last section to summarize the contribution of this paper.

\section{The proposed model}

Based on previous literature, the variables affecting the export market focus. These variables used in the study are listed in Table 1 . As we can observe from the results of Table 1, there are 37 factors influencing the market development in food industry. We have tried to collect all these items from various resources so that it would present a comprehensive collection of all possible criteria influencing market development. 
Table 1

Research variable

\begin{tabular}{|c|c|c|}
\hline Row & Criteria & Reference \\
\hline 1 & Using writings Market & Miguel. 2007 \\
\hline 2 & Creating a Competitive Advantage & Munksgaard et al., 2012 \\
\hline 3 & Customers' needs and aspirations & Pitta, \& Pitta,2012 \\
\hline 4 & Implementing product development processes & Hong et al., 2009 \\
\hline 5 & Opportunities to use technology & Cheng \& Shiu, 2008 \\
\hline 6 & Expert knowledge in product innovation & Miguel, 2007 \\
\hline 7 & Internal strengths & Miguel, 2007 \\
\hline 8 & Partnership with foreign companies & Svendsen et al., 2011 \\
\hline 9 & Market space created by the company & Lee, 2008 \\
\hline 10 & Find new market space & Akgün et al., 2007 \\
\hline 11 & Level of ICT & Lee, 2008 \\
\hline 12 & Brand & Prašnikar \& Škerlj, 2006 \\
\hline 13 & Consumer buying behavior & Sun \& Wing, 2005 \\
\hline 14 & Reduce product delivery time & Miguel, 2007 \\
\hline 15 & Flexibility in product design and development & Pitta \& Pitta, 2012 \\
\hline 16 & Using triggers sales & Miguel, 2007 \\
\hline 17 & Customers understand the products of competitors & Miguel, 2007 \\
\hline 18 & Customers involved in product development & Lau, 2010 \\
\hline 19 & Corporate reputation & Miguel, 2007 \\
\hline 20 & Inter-agency coordination & Pitta \& Pitta,2012 \\
\hline 21 & Customer-oriented approach in innovation & Hong et al., 2009 \\
\hline 22 & A scenario Sale & Miguel, 2007 \\
\hline 23 & Product development data & Pitta \& Pitta,2012 \\
\hline 24 & Increased requirements & Lau, 2010 \\
\hline 25 & Participation in product design & Hong et al., 2009 \\
\hline 26 & Inventory management, sales & Miguel, 2007 \\
\hline 27 & Technological change & Lau, 2010 \\
\hline 28 & Shortening the product development time & Pitta \& Pitta, 2012 \\
\hline
\end{tabular}

\subsection{Data collection and sample}

The present study employs a questionnaire survey approach to collect data for testing the research hypotheses. The statistical population in this study includes manufacturers and exporters of food industry. In this study, method of sampling is simple random sampling. Among the exporters and manufacturers, the study selected 214 people randomly and questionnaires were given. To analyze the data, descriptive statistics were used to sort the data in the second part of the data analysis is performed based on statistical inference. In this paper, for analyzing the data we use LISREL and AMOS software packages.

\subsection{Assessing reliability}

The reliability of the measurements in the survey was tested using Cronbach's a. Hair et al. (1998) stated that a value of 0.70 and higher is often "considered the criterion for internally consistent established factors". The Cronbach's a coefficients in parentheses indicating the internal consistency reliability of the measures $(\mathrm{a}=0.899)$.

\section{Analysis and results}

The proposed study designs a questionnaire and distributes it among 263 experts. Cronbach alpha is calculated as 0.89 , which is well above the minimum desirable limit of 0.70 . In this study, Cronbach alpha has been calculated as 0.899 and Table 2 demonstrates the results.

Table 2

Reliability Statistics

Cronbach's Alpha

0.899

Cronbach's Alpha Based on Standardized Items

$\mathrm{N}$ of Items

0.90

In addition, Kaiser-Meyer-Olkin Measure of Sampling Adequacy was 0.77 (Approx. Chi-Square= $4522.552 \mathrm{df}=630 \mathrm{Sig} .=0.000$ ), which also confirms the results of our survey. Table 3 demonstrates the results. 
Table 3

KMO and Bartlett's Test

\begin{tabular}{lll}
\hline & Kaiser-Meyer-Olkin Measure of Sampling Adequacy & 0.77 \\
\hline Bartlett's Test of Sphericity & Approx. Chi-Square & 4522.552 \\
& Df & 630 \\
& Sig. & 0.000 \\
\hline
\end{tabular}

In this section, research data using scientific methods are investigated and they are analyzed in two parts. First, descriptive statistics are used to sort the data and then part of the data analysis is performed based on statistical inference. Factor analysis and structural equation analysis of the presumptive test was used and the primary question is to find out about important factors influencing product development and regulation of export market share. To answer the first question the exploratory factor analysis has been used. Table 4 and 5 present the results of analyzing the data.

Table 4

Descriptive Statistics

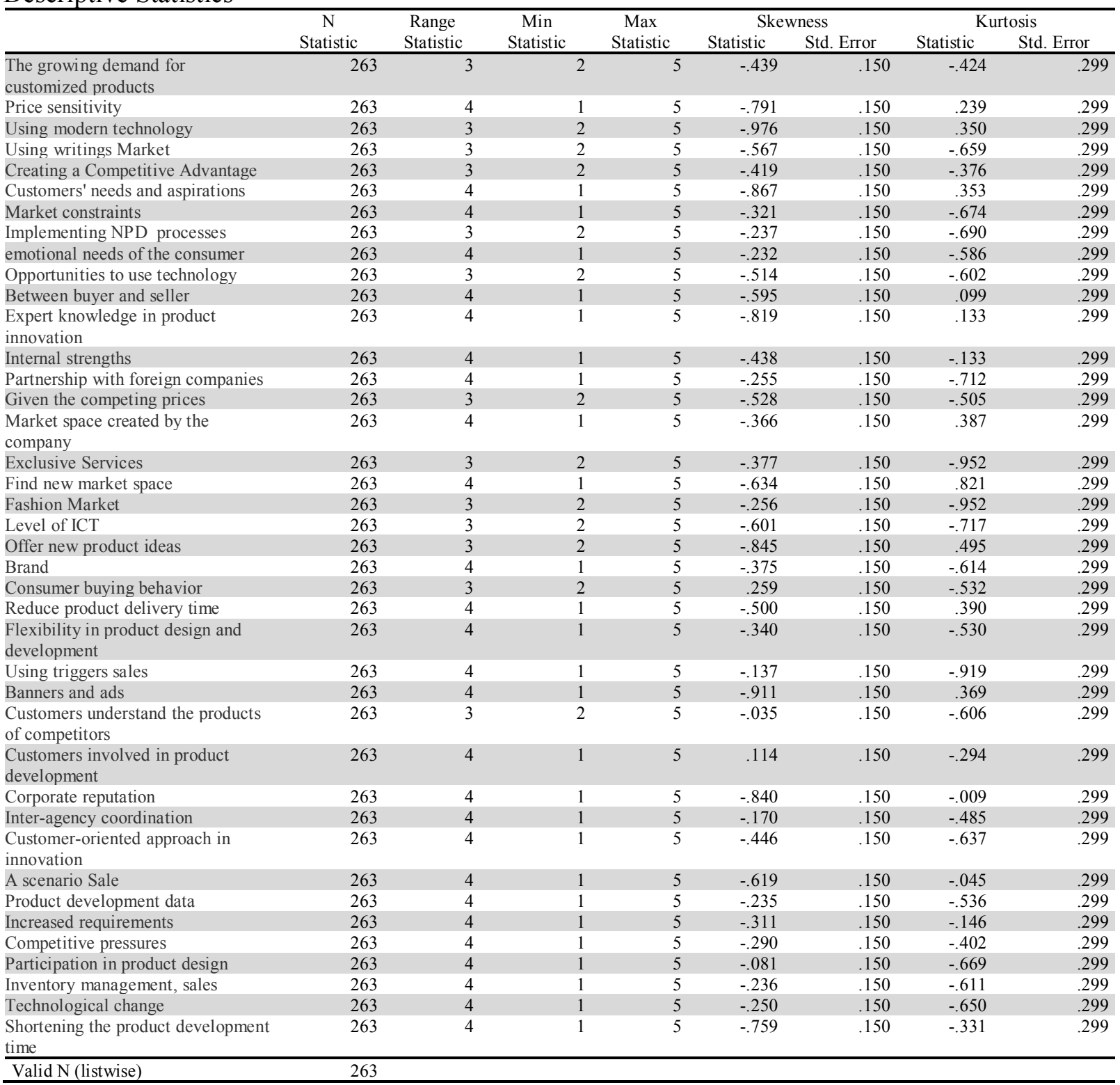


Table 5

Total Variance Explained

\begin{tabular}{|c|c|c|c|c|c|c|c|}
\hline \multirow[t]{2}{*}{ Component } & \multicolumn{3}{|c|}{ Initial Eigenvalues } & \multicolumn{3}{|c|}{ Extraction Sums of Squared Loadings } & \multirow{2}{*}{$\begin{array}{l}\text { Rotation Sums of } \\
\text { Squared Loadings } \\
\text { Total }\end{array}$} \\
\hline & Total & $\%$ of Variance & Cumulative \% & Total & $\%$ of Variance & Cumulative $\%$ & \\
\hline 1 & 8.906 & 24.739 & 24.739 & 8.906 & 24.739 & 24.739 & 3.701 \\
\hline 2 & 2.632 & 7.311 & 32.050 & 2.632 & 7.311 & 32.050 & 2.579 \\
\hline 3 & 2.081 & 5.781 & 37.831 & 2.081 & 5.781 & 37.831 & 2.554 \\
\hline 4 & 1.998 & 5.549 & 43.380 & 1.998 & 5.549 & 43.380 & 2.491 \\
\hline 5 & 1.879 & 5.220 & 48.601 & 1.879 & 5.220 & 48.601 & 2.395 \\
\hline 6 & 1.583 & 4.396 & 52.997 & 1.583 & 4.396 & 52.997 & 2.242 \\
\hline 7 & 1.461 & 4.058 & 57.054 & 1.461 & 4.058 & 57.054 & 2.099 \\
\hline 8 & 1.289 & 3.581 & 60.636 & 1.289 & 3.581 & 60.636 & 1.910 \\
\hline 9 & 1.159 & 3.220 & 63.855 & 1.159 & 3.220 & 63.855 & 1.756 \\
\hline 10 & 1.088 & 3.022 & 66.878 & 1.088 & 3.022 & 66.878 & 1.712 \\
\hline 11 & 1.033 & 2.868 & 69.746 & 1.033 & 2.868 & 69.746 & 1.670 \\
\hline 12 & .917 & 2.547 & 72.293 & & & & \\
\hline 13 & .840 & 2.334 & 74.627 & & & & \\
\hline 14 & .784 & 2.177 & 76.804 & & & & \\
\hline 15 & .707 & 1.963 & 78.767 & & & & \\
\hline 16 & .682 & 1.896 & 80.662 & & & & \\
\hline 17 & .670 & 1.861 & 82.524 & & & & \\
\hline 18 & .644 & 1.789 & 84.313 & & & & \\
\hline 19 & .592 & 1.644 & 85.957 & & & & \\
\hline 20 & .558 & 1.549 & 87.506 & & & & \\
\hline 21 & .504 & 1.401 & 88.907 & & & & \\
\hline 22 & .453 & 1.259 & 90.166 & & & & \\
\hline 23 & .419 & 1.164 & 91.330 & & & & \\
\hline 24 & .355 & .985 & 92.315 & & & & \\
\hline 25 & .338 & .939 & 93.254 & & & & \\
\hline 26 & .315 & .874 & 94.127 & & & & \\
\hline 27 & .297 & .826 & 94.953 & & & & \\
\hline 28 & .288 & .801 & 95.754 & & & & \\
\hline 29 & .259 & .721 & 96.475 & & & & \\
\hline 30 & .240 & .666 & 97.141 & & & & \\
\hline 31 & .224 & .622 & 97.763 & & & & \\
\hline 32 & .196 & .545 & 98.308 & & & & \\
\hline 33 & .173 & .481 & 98.788 & & & & \\
\hline 34 & .158 & .440 & 99.228 & & & & \\
\hline 35 & .150 & .416 & 99.645 & & & & \\
\hline 36 & .128 & .355 & 100.000 & & & & \\
\hline
\end{tabular}

Extraction Method: Principal Component Analysis.

Fig. 1 demonstrates Eigenvalues for each factor and a special agent with the highest value indicates that after six factors, the curve becomes smooth and we choose six factors for the proposed study.

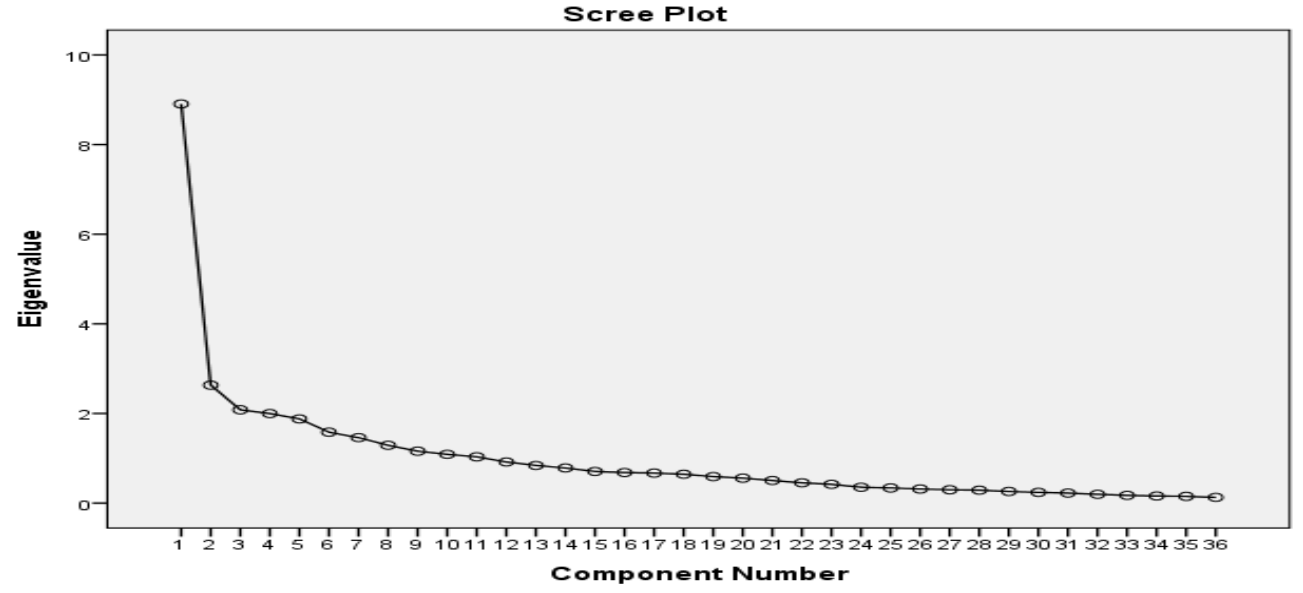

Fig. 1. Scree plot

Table 6 demonstrates the results of component matrix on eleven factors, before and after varimax rotation. 
Table 6

Component Matrix

\begin{tabular}{|c|c|c|c|c|c|c|c|c|c|c|c|}
\hline \multicolumn{12}{|c|}{ Comnonent } \\
\hline & 1 & 2 & 3 & 4 & 5 & 6 & 7 & 8 & 9 & 10 & 11 \\
\hline A37 & .714 & & & & & & & & & & \\
\hline A39 & .677 & & & & & & & & & & \\
\hline A 38 & .675 & & & & & & & & & & \\
\hline A15 & .627 & & & & & & -.364 & & & & \\
\hline $\mathrm{A} 4$ & .625 & & & & & & & & & & \\
\hline A44 & .611 & & & & -.429 & & & & & & \\
\hline $\mathrm{A} 45$ & .589 & & & & & & & & & .364 & \\
\hline A36 & .586 & & & & & & & & & & \\
\hline $\mathrm{A} 41$ & .579 & & & -.447 & & & & & & & \\
\hline A29 & .576 & & & .436 & & & & & & & \\
\hline A 10 & .573 & & & & & & & & -.449 & & \\
\hline A 23 & .558 & & & & -.344 & & & & & & \\
\hline $\mathrm{A} 40$ & .555 & -.451 & & & & & & & & & \\
\hline A 24 & .536 & .340 & & & & & & & & -.344 & \\
\hline $\mathrm{A} 32$ & .521 & -.371 & & & & & & & & & \\
\hline A26 & .516 & & .341 & & & .413 & & & & & \\
\hline $\mathrm{A} 42$ & .515 & & & & & -.399 & & & & & \\
\hline $\mathrm{A} 12$ & .499 & .479 & & & & & & & & & \\
\hline A14 & .497 & & & & .349 & & & & & & \\
\hline A7 & .496 & & & & & & .375 & & & & \\
\hline A 20 & .481 & & & & & -.378 & & & & & \\
\hline A8 & .468 & & & & & & -.363 & & & & \\
\hline A 27 & .455 & & .341 & & & & & & & & \\
\hline $\mathrm{A} 33$ & .445 & -.374 & & & & & & & & & \\
\hline A18 & .432 & & & & .346 & & & -.340 & & & \\
\hline A11 & & .495 & & & -.357 & & & & & & \\
\hline $\mathrm{A} 30$ & .461 & -.472 & & & .370 & & & & & & \\
\hline A 25 & .338 & .460 & & -.359 & & & & & & & \\
\hline A3 & & & -.638 & & & & .342 & & & & \\
\hline A 13 & & .349 & .495 & & & & & & & & \\
\hline A 31 & & & .490 & & & .379 & & .335 & & & \\
\hline A34 & & -.367 & & .514 & & & .408 & & & & \\
\hline A16 & .413 & & & & .424 & & & & & & \\
\hline A43 & .437 & & .367 & & & -.451 & & & & & \\
\hline A19 & & & & & .427 & -.438 & & & & & .350 \\
\hline A 21 & & .405 & & .455 & & & & .518 & & & \\
\hline
\end{tabular}

Extraction Method: Principal Component Analysis. a. 11 components extracted.

Table 7

Rotated Component Matrix ${ }^{\mathrm{a}}$

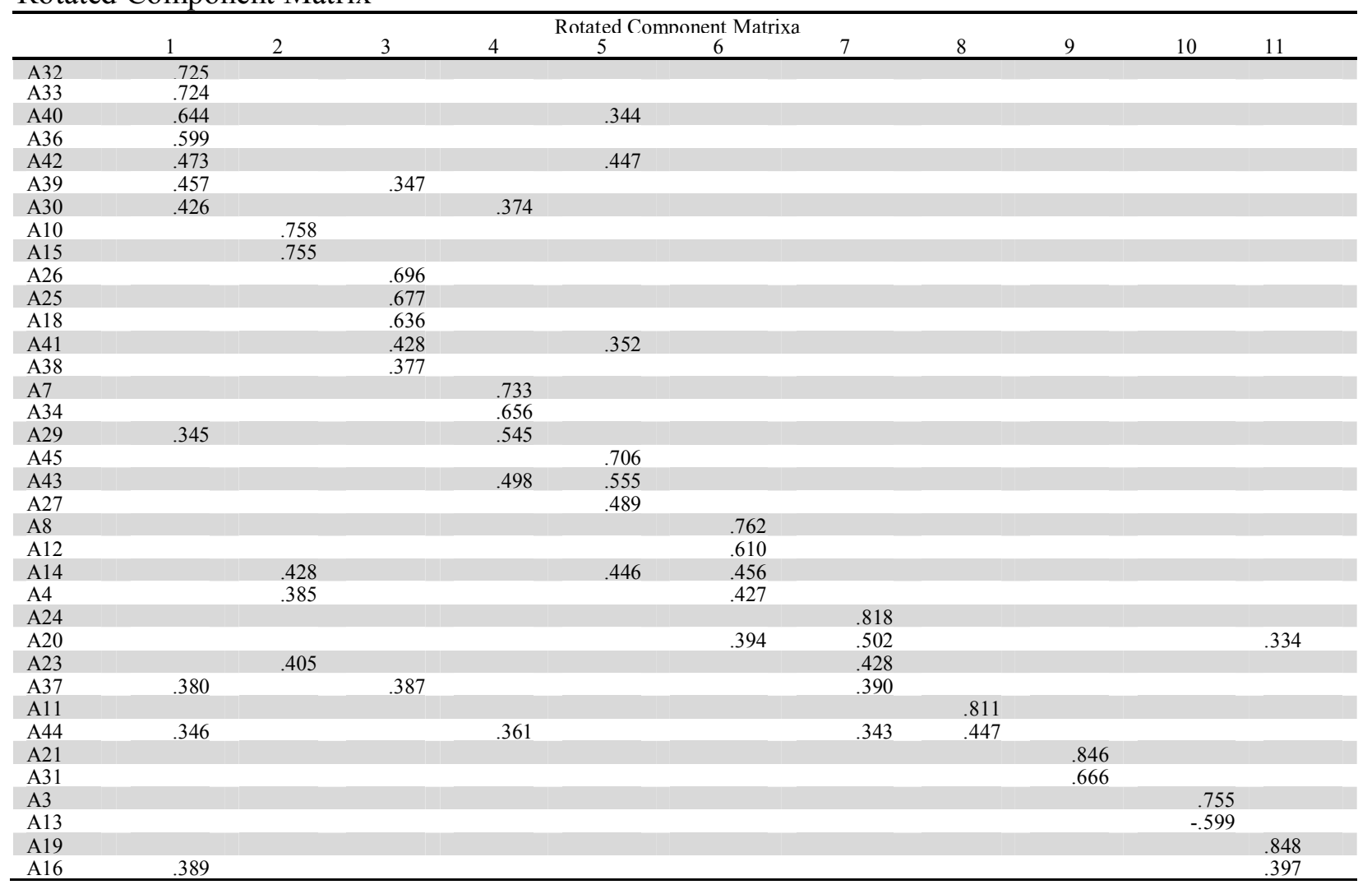


Note that extraction method in Table 7 was based on Principal Component Analysis. Rotation Method, Varimax with Kaiser Normalization and rotation converged in 11 iterations. The proposed study determined six important factors influencing product development including partnership, Intelligence Information, introducing Strategy, differentiating Strategy, Process research and development and market survey strategies. The results of the implementation of factor analysis have provided six factors, which are explained next.

\subsection{Interpretation of the results of the factor analysis}

Table 9

The summary of the results of non-standard model

\begin{tabular}{|c|c|c|c|c|}
\hline & Indexes & Important coefficient & P-value & Result \\
\hline \multirow{6}{*}{ Partnership Strategy } & Participation in product design & 0.56 & $<0.001$ & Accept \\
\hline & Customers understand the products of competitors & 0.39 & $<0.001$ & Accept \\
\hline & Customers involved in product development & 0.61 & $<0.001$ & Accept \\
\hline & Inter-agency coordination & 0.40 & $<0.001$ & Accept \\
\hline & Customer-oriented approach in innovation & 0.59 & $<0.001$ & Accept \\
\hline & Transmission change and product development & 0.27 & $<0.001$ & Accept \\
\hline \multirow{5}{*}{$\begin{array}{l}\text { Intelligence } \\
\text { Information }\end{array}$} & Implementing product development processes & 0.57 & $<0.001$ & Accept \\
\hline & Internal strengths & 0.43 & $<0.001$ & Accept \\
\hline & Expert knowledge in product innovation & 0.34 & $<0.001$ & Accept \\
\hline & Level of ICT & 0.42 & $<0.001$ & Accept \\
\hline & Using Market Studies & 0.37 & $<0.001$ & Accept \\
\hline \multirow{8}{*}{ introducing Strategy } & A scenario Sale & 0.38 & $<0.001$ & Accept \\
\hline & Brand & 0.24 & $<0.001$ & Accept \\
\hline & Consumer buying behavior & 0.46 & $<0.001$ & Accept \\
\hline & Market space created by the company & 0.61 & $<0.001$ & Accept \\
\hline & Inventory management, sales & 0.40 & $<0.001$ & Accept \\
\hline & Increase the requirements in product development & 0.70 & $<0.001$ & Accept \\
\hline & Shortening the product development time & 0.55 & $<0.001$ & Accept \\
\hline & Reduce product delivery time & 0.50 & $<0.001$ & Accept \\
\hline \multirow{3}{*}{ Market Survey } & Customer needs & 0.56 & $<0.001$ & Accept \\
\hline & Using technology opportunities & 0.53 & $<0.001$ & Accept \\
\hline & Find new market space & 0.68 & $<0.001$ & Accept \\
\hline
\end{tabular}

In addition, the results of our test does not confirm the effects for five variables including Partnership with foreign companies, Flexibility in product design and development, Corporate reputation, Technological change and Using triggers sales.

\section{Discussion and conclusions}

Regarding the results of first question, we can offer 6 hypotheses that identified by exploratory factor analysis and by the Confirmatory factor analysis they reject and accept of and ranking of each of the components of Export market share. Table 10 shows details of our findings on six variables.

\section{Table 10}

The summary of six important factors

\begin{tabular}{lccc}
\hline The main hypothesis & $\mathrm{P}$ & Estimate & Result \\
\hline Intelligent Information & $\mathrm{P}<0.001$ & 2.379 & Accept \\
Process Research and Development & $\mathrm{P}<0.001$ & 2.068 & Accept \\
Strategy introduced & $\mathrm{P}<0.001$ & 1.839 & Accept \\
Participation Strategy & $\mathrm{P}<0.001$ & 1.000 & Accept \\
Market Survey & $\mathrm{P}<0.001$ & 1.471 & Accept \\
Differentiation strategy & 0.615 & 0.005 & Reject \\
\hline
\end{tabular}


Fig. 2 shows details of the relationship among various components in standard form.

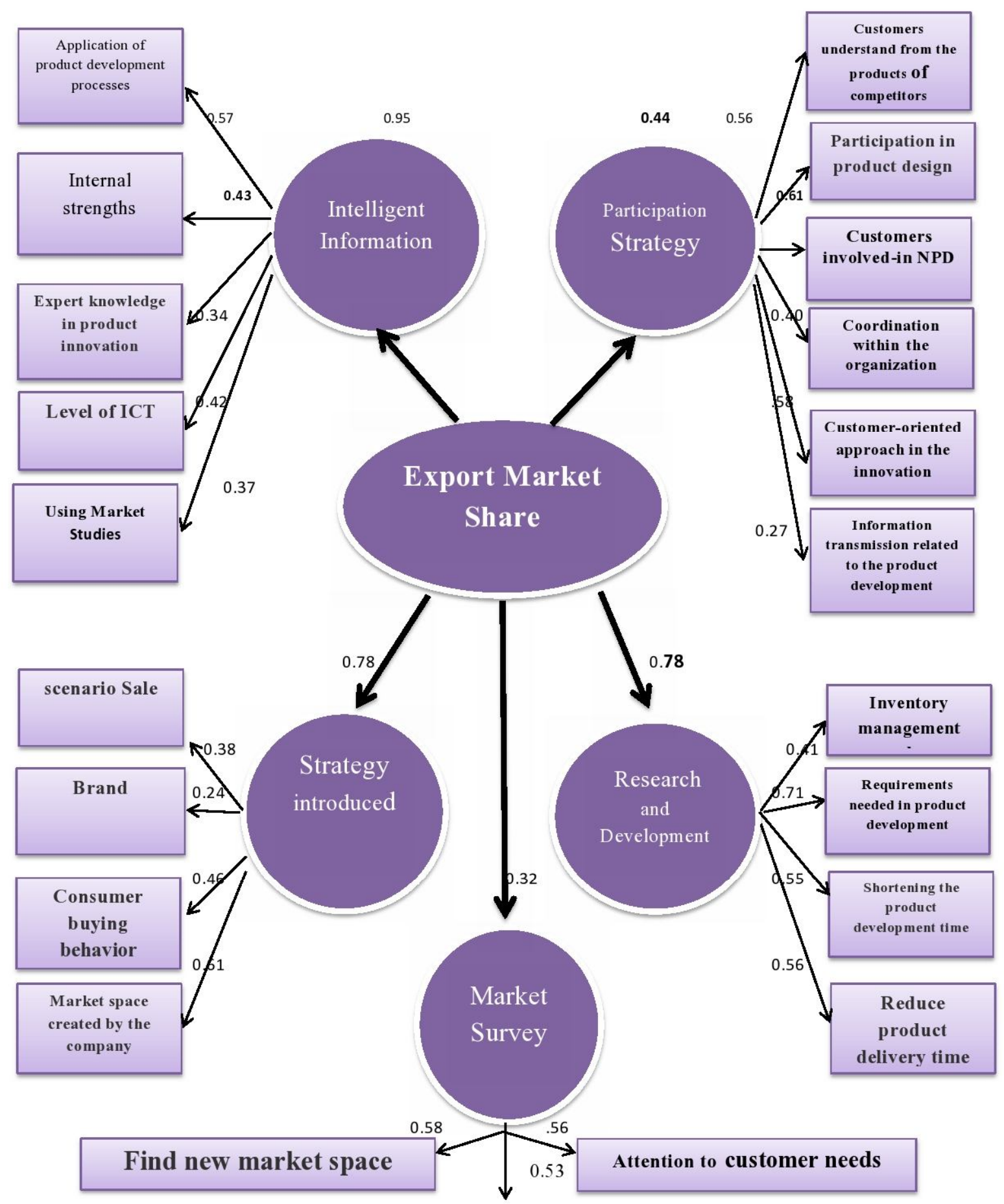

Application of technology opportunities

Fig. 2. The results of survey in standard form

Based on the results of confirmatory factor analysis, the importance of each factor on Export market share are summarized in Table 11 as follows, 
Table 11

The results of confirmatory factor analysis

\begin{tabular}{lc}
\hline Factor & Important coefficient \\
\hline Intelligence Information & .98 \\
Process Research and Development & .89 \\
Introducing Strategy & .88 \\
Partnership Strategy & .67 \\
Market Survey & .56 \\
\hline
\end{tabular}

\section{References}

Akgün, A. E., Byrne, J. C., Lynn, G. S., \& Keskin, H. (2007). Team stressors, management support, and project and process outcomes in new product development projects. Technovation, 27(10), 628-639.

Andersen, P. H., \& Munksgaard, K. B. (2009). Collaborative product development and situated knowledge contexts: the case of non-durable food products. European Journal of Innovation Management, 12(2), 200-222.

Cheng, C. C. J., \& Shiu, E. C. (2008). Critical success factors of new product development in Taiwan's electronics industry. Asia Pacific Journal of Marketing and Logistics, 20(2), 174-189.

Darawong, C., \& Igel, B. (2012). Acculturation of local new product development team members in MNC subsidiaries in Thailand. Asia Pacific Journal of Marketing and Logistics, 24(3), 351-371.

Danese, P., \& Filippini, R. (2010). Modularity and the impact on new product development time performance: Investigating the moderating effects of supplier involvement and interfunctional integration. International Journal of Operations \& Production Management, 30(11), 1191-1209.

David, F. R. (1989). How companies define their mission. Long range planning,22(1), 90-97.

Hair, J.F., Anderson, R.E., Tatham, R.L., and Black, W.C. (1998). Multivariate Data Analysis. $5^{\text {th }}$ ed., Englewood Cliffs, NJ: Prentice Hall.

Hong, Y., Pearson, J. N., \& Carr, A. S. (2009). A typology of coordination strategy in multiorganizational product development. International Journal of Operations \& Production Management, 29(10), 1000-1024.

Lau, A. K., Tang, E., \& Yam, R. (2010). Effects of supplier and customer integration on product innovation and performance: empirical evidence in Hong Kong manufacturers. Journal of Product Innovation Management, 27(5), 761-777.

Lee, L. T. S. (2008). The effects of team reflexivity and innovativeness on new product development performance. Industrial Management \& Data Systems, 108(4), 548-569.

Meybodi, M. Z. (2013). The links between lean manufacturing practices and concurrent engineering method of new product development: An empirical study. Benchmarking: An International Journal, 20(3), 362-376.

Miguel, P. A. C. (2007). Innovative new product development: a study of selected QFD case studies. The TQM Magazine, 19(6), 617-625.

Munksgaard, K. B., \& Freytag, P. V. (2011). Complement or involvement in product development. Journal of Business \& Industrial Marketing, 26(4), 286-298.

Munksgaard, K. B., Clarke, A. H., Storvang, P., \& Erichsen, P. G. (2012). Product development with multiple partners: Strategies and conflicts in networks. Industrial Marketing Management, 41(3), 438-447.

Pitta, D., \& Pitta, E. (2012). Transforming the nature and scope of new product development. Journal of Product \& Brand Management, 21(1), 35-46.

Prašnikar, J., \& Škerlj, T. (2006). New product development process and time-to-market in the generic pharmaceutical industry. Industrial Marketing Management, 35(6), 690-702. 
Richtnér, A., \& Åhlström, P. (2010). Top management control and knowledge creation in new product development. International Journal of Operations \& Production Management, 30(10), 1006-1031.

Shamsuzzoha, A., Kyllönen, S., \& Helo, P. (2009). Collaborative customized product development framework. Industrial Management \& Data Systems, 109(5), 718-735.

Svendsen, M. F., Haugland, S. A., Grønhaug, K., \& Hammervoll, T. (2011). Marketing strategy and customer involvement in product development. European Journal of Marketing, 45(4), 513-530.

Swan, H., \& Pitta, D. (2010). The ultimate in new product design: molding the product concept to user learning needs. Journal of Product \& Brand Management, 19(4), 286-294.

Sun, H., \& Wing, W. C. (2005). Critical success factors for new product development in the Hong Kong toy industry. Technovation, 25(3), 293-303. 